\title{
Benkő Samu
}

\section{Debreczeni Márton és az EME}

A cím láttán, illetőleg olvastán könnyen felmerülhet a gyanú, hogy vajon nem aggkori szellemi megbicsaklás helyezte egymás mellé a két nevet: az 1802-ben született és 1851-ben már meghalt tudós bányamérnökét és az 1859-ben alapított erdélyi tudós intézményét? Nincs-e valami tévedés az évszámok körül? Nem tagadva az élemedett kor naponta tapasztalható keserves kisérö jelenségeit, elmondhatom, hogy ez alkalommal nem történt emlékezetbeli botlás.

Mert igaz ugyan, hogy az. Erdélyi Múzeum-Egyesület alakuló közgyülésére 1859. november 23-25-én került sor, mégis joggal nevezhetjük EME-embereknek azoknak az élők sorából korábban eltávozott erdélyi magyarokat, akik évekkel megelőzően felvetették, kezdeményezték, hogy ez a kis ország rakja le a maga magyar tudományos intézményeinek az alapjait, illetöleg akik olyan szellemi főembereknek bizonyultak, akikben élt a remény és az igény, hogy életmúvük írásos és tárgyi emlékei előbb-utóbb intézményes örzési helyre leljenek itt bent a hazában.

Nézzünk csak szét egy kicsit az EME régi emberei között. Azok között, akiket az 1909-1942-es Emlékkönyv is így nevez meg: Az EME régi emberei. Első helyen említjük az 1855-ben meghalt történetíró Kemény Józsefet, aki unokaöccsével, Kemény Sámuellel közösen írt, és az 1842-es erdélyi országgyüléshez címzett levélben - „honfiúi és honpolgári érzelmük sugallatának engedve” - felajánlják 15000 kötetet meghaladó könyvtárukat, több ezerre menő kézirat- és oklevélgyüjteményüket, valamint más muzeális értékeiket a felállítandó erdélyi múzeumnak.

Kemény Józseffel azonos évben, 1795-ben született az EME másik embere, Bölöni Farkas Sándor, aki többek között arról is nevezetes, hogy 1829-ben Lázár László kancellárhoz benyújtott nevezetes memorandumában - Kelemen Lajos fogalmazása szerint - ,vázlatos, de céltudatos múzeumi programot" állított össze.

Maguk az alapítók is nagyon jól tudták tehát, hogy az EME története nem az 1859-es alapító közgyüléssel kezdődik, de még csak nem is a reformkori közhatalmi körben: országgyülésen, vármegyei közgyüléseken elhangzott javaslatokkal, hanem azokkal a tudományos teljesítményekkel, melyeket létrehozóik intézményi erödrendszer oltalmába szerettek volna helyezni.

Ha csak rápillantunk az alapító Mikó Imre írásainak a könyvészeti jegyzékére, láthatjuk, hogy elöszeretettel foglalkozott azoknak az erdélyi tudósoknak az életével és munkásságával, akik tehetségüket, szakterületük müvelése mellett, az erdélyi magyar tudományosság összefogására is felhasználták. Így írt Mikó tanulmányt a tudós emberekből álló magyar társaság gondolatát felvetỏ Bod Péterről, szentelt monográfiát az „erdélyi históriás szekrényt” kezdeményező Benkő Józsefnek és adta ki részletes életrajzzal bányamérnök barátjának, a korán elhunyt Debreczeni Mártonnak a magyar honfoglalásról írt höskölteményét.

Az Erdélyi Mizeum-Egyesïlet története címủ, 1909-ben megjelent tanulmányában Kelemen Lajos hangsúlyozza, hogy Mikó Imre Debreczeni Márton kéziratban heverö eposzának a kiadásával nemcsak a múlt dicsőségének a feltüntetésére vállalkozott, hanem nehéz időben, 1854-ben $A$ kióvi csata előszavában ismételten han- 
goztatja ez Erdélyi Múzeum-Egyesület szükségességét, tehát egy olyan intézményét, „hol a múlt minden emlékét összegyüjtve örizni és fenntartani lehessen“.

Tegyük ehhez hozzá még azt is, hogy ugyancsak nehéz idöben, 1960-ban Debreczeni Mártonra emlékezve, a másik Mikó Imre, a mi kortársunk, a kiváló nemzetiségi jogász, Döbrentei Gábor folyóirata, az Erdélyi Muzéum köré tömörülö nagy reményü erdélyi fiatalok müvelödéstörténeti szerepét hangsúlyozva emlékeztet rá, hogy e fiatalok között ott volt a kolozsvári Református Kollégium diákja, Debreczeni Márton is.

Az 1851-ben meghalt Debreczeni Márton és az 1859-ben végre megalakult EME között a szétbonthatatlan kapcsolat jelzését Mikó Imre azzal tetézte, hogy 1854-ben a saját költségén kiadott hősköltemény bevezetéseként megírta és közrebocsátotta ,,a közönséges származású, de nem közönséges életủ férfi” életrajzát és méltatta szépirodalmi és tudományos munkásságát. Mikó Imre azzal is az Erdélyi Múzeum-Egyesülethez kapcsolta Debreczeni Mártont, hogy halála után magához vette kézirati hagyatékát, és abból elöször az említett hőskölteményt rendezte sajtó alá és bocsátotta közzé, majd rendbe rakta az egész kézirati hagyatékot. Természetesen Mikót barátjának és egykori kincstári munkatársának nemcsak költöi teljesítménye érdekelte, hanem egész életmủve, így figyelme természetesen kiterjedt minden papírra vetett gondolatára. Nemsokára az ő gondoskodása juttatta ezeket az iratokat az Erdélyi Múzeum-Egyesület tulajdonába: a levéltárba és a kézirattárba. Sorsunk alakulásának furcsasága következtében a mai kutató a Debreczeni-kéziratokat két helyt keresheti: a Román Országos Levéltár kolozsvári Igazgatóságának gondozásában lévö múzeumi levéltárnak az állagában, mégpedig az egyesített MikóRhédey családi levéltárban, és a kolozsvári Egyetemi Könyvtár kézirattárában, ahol ugyancsak az eredetileg Egyesületünkre testált és beköttetett kéziratokat örzik (és amelyek visszaszolgáltatását türelmetlenül várjuk).

Magam egyetemi hallgatóként a Farkas utcába költöztetett egyesületi levéltárban találkoztam elöször Debreczeni Márton kézirataival. A soproni bányatörténész, Faller Jenö akkoriban írta Debreczeni Márton (1802-1851) bányamérnök élete és munkássága címü tanulmányát, amelyet aztán a Bányászati Lapok 1951. évfolyama 20. számában jelentetett meg. Az akkori idők nehéz (mondhatnám lehetetlen) kutatási feltételei között Faller Jenő Jakó Zsigmond professzortól, az EME levéltára akkori vezetőjétöl kért felvilágositást a Kolozsvárott örzött Debreczeni-kéziratokról, ílletve a tudós bányamérnökre vonatkozó irományokról. A levéltári forrásokkal ismerkedő diákként láthattam tehát a kutatószobában Jakó Zsigmond asztalán a Debreczeni-kéziratokat, melyekről aztán a soproni professzor levélbeli tájékoztatást kapott. Ennek az egyesületi levéltárban szerzett elsö élménynek lett szerves következménye, hogy néhány év múlva az Erdélyi müszaki és gazdasági értelmiség kialakulásának kérdéséröl írt (1956-ban megjelent) tanulmányomban számba vehettem az erdélyi bányász értelmiség kialakulásának a körülményeit és méltathattam Debreczeni különleges szerepét az erdélyi bányaipar technikai színvonalának emelésében. Ėvek teltével, éppen a Ceauşescu rendszer haldoklása idején ismét visszatérteın Debreczeni Márton kézirataihoz. Azokat az irományait vettem szemügyre, melyeket az Erdélyi Nemzeti Múzeum könyvtárának kézirattárában helyeztek el, és amelyek, mint jeleztem, ma a kolozsvári Egyetemi Könyvtár kézirattár örizetében vannak. Itt a katalógusban 13 tétel jelöl Debreczeni-kéziratot, ezek- 
böl 3 szótár-fogalmazvány, melyekröl Debreczeni Márton szótárszerkesztményei címmel 1991-ben tanulmányt tettem közzé.

Itt emlékezem meg arról is, hogy a múzeumi levéltár egyik másik fondjában, a zilahi Református Kollégium levél- és kéziratgyüjteményében bukkant rá Dani János Debreczeni Márton két 19. század eleji román nyelvủ nyomtatott versére, melyek 1818-ban jelentek meg. Dani János ismertetését ezekról a katonabúcsúztatókról 1960-ban olvastuk a Korunk hasábjain.

Mivelhogy mai ünnepi megemlékezésünkön előadóink részletesen szólnak a bányamérnökröl, a feltalálóról és a költőről, számomra már csak az a feladat hárul, hogy néhány szóban Debreczeni érdemdús egyéniségét, illetöleg szellemi habitusának legjellemzőbb vonásait próbáljam magunk elé idézni.

Alkotómunkára termett sokoldalú egyéniség volt. Az alkotómunkához megkívántató szellemi fegyverzettel a kolozsvári Református Kollégiumban és a 1763ban létesített selmecbányai Bányászati Akadémián szerelkezett fel. A kolozsvári kollégium diákjaként, az antikvitás görög és latin auktoraira támaszkodó literátori műveltség mellett, viszonylag korszerü matematikai, fizikai és vegytani ismeretekre is szert tehetett, melyeket aztán az európai hírủ felső-magyarországi akadémián ásványtani, fémkohászati és bányamủvelési ismeretekkel toldhatott meg. Hangsúlyozza, hogy a tudományok igazi mibenlétét Selmecbányản ismerte meg.

Tudatában volt annak, hogy némelyek szemében a költöi és a mérnöki munka mélyén ellentétes módszerek húzódnak meg, de ö pontosan ezt az ellentételezettséget tudta mesterien föloldani. Felismerte, hogy ihletre és képzelöerőre mind a két területen nagy szüksége van az alkotó embernek.

Sokoldalúságához párosult kísérletezö kedve is. Kísérletezett a szépirodalomban éppen úgy, mint a müszaki tudományokban, és kísérleti telepnek tekintette a Kárpátok ércben gazdag hegyvonulatait éppen úgy, mint Erdély iparosodásának első szálláshelyeit, az érckohókat. Vörösmarty Mihály irodalomtörténeti korszakot nyitó eposzának, a Zalán futásának megjelenése elött höskölteményt írt a magyar honfoglalásról, Zalatnán gözgépet alkalmazott, és az 1848-49-es forradalom idején Kossuth Lajos mellett dolgozva minisztériumi fötisztviselőként ő biztositja, hogy a honvédség fegyverzetét elóállító hadiüzemek folyamatosan hozzájussanak a bányászati nyersanyaghoz, a fémércekhez.

Alkotótevékenysége nemcsak az erdélyi föld kincseit kiaknázỏ bảnyamérnöki tevékenységében tünt ki, hanem szaktudománya múvelésében is, és bizonyos tudományszervezési akciókban. Egyike azoknak, akik 1838-ban létrehozzák Zalatnán a bányászati kaszinót azzal a rendeltetéssel, hogy tagjai elöadásokkal, vitákkal, a külföldi szakirodalom rendszeres figyelésével és saját eredményeik publikálảsảval „a bányászati szorgalomba bevágó tudományok és müvészet elöhaladásảt eszközöljék".

Tudományszervezési találékonysága abban is megmutatkozott, ahogy hozzálátott bányászati szakszótárak szerkesztéséhez. Egyesületünk kézirattárába hảrom szótárszerkesztményének a fogalmazványa került be. Ezekböl megismerhetjük munkamódszerét, azt, hogy a szótárszerkesztést közösségi feladatnak tekintette. Munkáját azzal kezdte, hogy összeállította az eltervezett német-magyar „bányászati müszótár", illetőleg a ,sóbányászati német-magyar mủszótár" német címszavainak a jegyzékét, és azt elküldte az Erdélyben dolgozó magyar bányamérnököknek azzal a kéréssel, hogy megfelelö magyar szót javasoljanak valamennyi német ter- 
minus jelentésének anyanyelvünkön való visszaadására. A szótárszerkesztö előmunkálatok különböző fázisait rögzitő kéziratokból megállapíthatjuk, hogy Debreczeni Márton a bányatudományokban és a magyar nyelvben járatos tizenkét munkatársát sorakoztatta fel maga köré, hogy közös eröfeszitéssel megtalálják a német szakkifejezések ezreinek a magyar megfelelöit. A tudományos együttmunkálkodásnak értékes emlékei ezek a szótárszerkesztmények, és mai napig elható magatartásbeli iránymutatás olvasható ki belölük.

A reformkori magyar akadémiai tudománypolitika dicséretére el kell mondanom, hogy a mérnök-költő szótárszerkesztési munkálkodása beilleszkedett abba az akadémiai kezdeményezésbe, amely feladatul tủzte ki szakszótárak szerkesztését. Teleki József akadémiai elnök még mielött Erdély fökonnányzója, gubernátora lett volna, maga kezdte sürgetni a magyar „,bányászati münyelv” megteremtését és ennek érdekében szorgalmazta honos magyar kifejezések, szólásmódok összegyüjtését és rendszerezését.

Hangsúlyozom. hogy Debreczeni Mártonnak a hủség dolgában van mondandója a mai erdélyi magyar ember számára. Hüségét mindvégig megörizte az anyanyelvü szellemi munkálkodáshoz.

Debreczeni Márton nyelvi tekintetben is talpig erdélyi ember volt. Amellett, hogy anyanyelvét költői szinten gyarapította, román nyelven irt versekkel és német nyelven szerkesztett bányászati szakszövegekkel bizonyította, hogy az Erdélyben együtt lakó népeket nyelvileg egyenrangúaknak tekintette. Nyelvi toleranciájának ékes bizonyítéka az a tervezete, melyet 1848. szeptember 6-án fogalmazott a Kossuth Lajos vezette magyar pénzügyminisztérium ,bányászati osztályigazgató helyetteseként” a selmeci Bányászati Akadémia átszervezéséröl. Az akadémia egykori diákjaként tudta, hogy az intézet közvetlenül a bécsi udvari bányakamarának volt alárendelve, és kizárólagos oktatási nyelve a német volt. A forradalmi változások rendjén Debreczeni azt javasolta, hogy az Akadémiát helyezzék a magyar pénzügyminisztérium felügyelete alá, és illő óvatossággal vezessék be a magyar előadási nyelvet úgy, hogy a magyar mellett a német is, mint tanítási nyelv huzamosabb időre megtartassék. Bölcsen kifundált javaslatát érvekkel támasztja alá: „,különös figyelmet érdemel ugyanis azon körülmény, hogy a magyar nyelv bányászati irodalommal még nem bír, s éppen ezért értelmes bányásznak, ki nem akar megelégedni az Akadémián tanultakkal, hanem a tudománnyal lépést tartva haladni kíván, a német nyelvnek tudása, mely a bányászati tudományokra nézve a legbővebb forrásokkal bír, múlhatatlanul szükséges".

Toleranciával párosuló hüségét anyanyelvéhez csak dúsítottảk azok az érzelmek, melyek szülöföldjéhez kötötték. Mikó Imre idézi Debreczeninek selmeci diákkorában, 1824-ben egy barátjához intézett levelét: ebben nélkülözések közepette vállalt szülöföldszeretetéről így vall: „Tanulásomat sehogy sem hagyom félbe, akármint hủzzam is $\mathrm{ki}$. Ha azon cosmopoliticum principiumom lenne, mi sok nemzeteknél oly nagy becsben van: ubi bene ibi patria, könnyü volna muszkaországi stipendiumot nyernem, s Szibériában idővel még nagy úr lehetnék; de a natale solum (szülőföld) lekötne engemet még akkor is, ha ott többé senkim sem lenne."

A natale solum magához kötötte egészen a Házsongárdi temetőig, ahol - mint az egyre pusztuló síremlékek jelzik - az EME többi nagyjainak, Bölöni Farkas Sándornak, Brassai Sámuelnek, Ujfalvi Sándornak, Mikó Imrének a nyugvóhelye közelében alussza örök álmát. 